\title{
Moral Legitimacy in Controversial Projects and its relationship with Social License to Operate: A Case Study
}

\begin{abstract}
Moral legitimacy entails intrinsic value and helps executives to convince firm's stakeholders and the general public of the ethical acceptability of an institution or its activities or projects. Social License to Operate (SLO) is the social approval of those affected by a certain business activity, and it is receiving increasing attention, especially in the context of controversial projects such as mining and public works. Moral legitimacy provides ethical support to SLO. Drawing from the Aristotelian-Thomistic tradition and taking substantive justice and the common good of society as the key references, this paper applies the Triple Font of Morality Theory and proposes four criteria which serve to evaluate moral legitimacy: (1) contribution of the project or activity to the common good in a better way than other alternatives (intended end), (2) morality of the means and procedures employed (means elected), (3) ethical evaluation of the situation including stakeholder concerns and needs (concurrent relevant circumstances), and (4) ethical evaluation of reasonably foreseeable consequences associated with the project and how to minimize possible damage or risks, and balance foreseeable negative consequences and benefits. The application of these criteria is illustrated through a project, presented as a case study, which certainly involved controversy and problems with SLO. The project was the construction of a rail tunnel for a high-speed train near the foundations of the Sagrada Familia, the well-known monumental church in Barcelona, Spain.
\end{abstract}

Keywords Aquinas, Aristotle, common good, controversial projects, justice, moral legitimacy, social license to operate, NIMBY syndrome, Sagrada Familia, the Triple Font of Morality Theory, virtues 


\section{Introduction}

Legitimacy is a widely used concept in political studies and one which has also come into use in business corporations and organizational theory. Legitimacy comes from the Latin legitimus, meaning "lawful," originally "fixed by law, in line with the law." Today, the meaning of legitimacy is also related with the acceptance or justification of the existence of an institution beyond "legality" (pertaining to the law). Thus, Berger (1981, p. 83ff.) defined legitimacy as the right possession of power. According to Brummer, this definition applied to corporations means that "their executives must convince the general public they exercise power in a justified manner." (Brummer 1991, pp. 73-74) Many other definitions of legitimacy have been proposed in the organizational context (Suchman 1995; see also Bitektine 2011, who presented a long bibliography). Suchman (1995) proposed a classification which has become quite popular among scholars of organization theory. He identified three primary forms of legitimacy: pragmatic, based on the self-interested calculations of an organization's most immediate audiences; moral, based on a positive normative evaluation of the organization and its activity, and cognitive, based on the comprehensibility and "takenfor-grantedness" of an organization through the array of established cultural accounts providing explanations for its existence (Meyer and Scott 1983, p. 201). Evaluating these three types of legitimacy, Koppell held that moral legitimacy is the "true meaning of the word legitimacy". He argued that both cognitive and pragmatic legitimacy imply only that an authority is acknowledged and submitted to, and "whether this authority deserves its status or imposes it is not a criterion for cognitive and pragmatic legitimacy.” (Koppell 2008, p. 182)

Corporations are generally seen as legitimate institutions and the justification of one's existence can be found in its contribution to the common good in different ways (the provision of goods and services which serve people's needs, creating wealth, providing jobs, developing knowledge, and so on). That is why, generally speaking, corporations receive support from society. However, such legitimacy can be questioned by the society (or some social groups) in the case of certain types of company or activity, or of specific projects that a company proposes to carry out. The latter may occur with activities which could damage the society or present risks to safety, which might have a

\footnotetext{
${ }^{1}$ Online Etymological Dictionary, "legitimate":

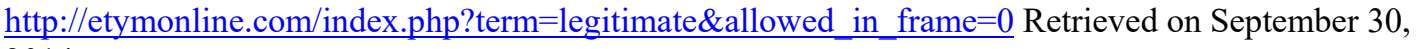
2014.
} 
negative impact on the environment, or because they involve occupying the territory of indigenous peoples. This can occur in projects involving mining, certain civil works, or nuclear power stations, among others. In extreme cases a lack of legitimacy can jeopardize an activity or a project or even the survival of a company.

In this context, the notion of Social License to Operate (SLO), or in short -although less precise- "license to operate", emerged in corporate argot in the first decade of the 2000s. In a broad sense, SLO referred to obtaining the approval of people affected by activities with a certain impact on local communities or neighborhoods. These are stakeholders, who should be considered. Some authors (Olander and Landin 2005, 2008; SDR Partners 2012, p. 6) have shown several factors affecting the stakeholder management process positively or negatively from the perspective of project implementation. However, scant attention has been paid to moral legitimacy in controversial projects thus far, and even less to how to evaluate it.

This article deals with both "moral legitimacy" and "social license to operate" and argues that both concepts are relevant in controversial projects. Its specific aim is to discuss the relationship between these concepts and to provide criteria to determine whether there is moral legitimacy in the case of controversial projects, with substantive justice and the common good as references, as we will explain below. A case study will illustrate some problems which can arise in controversial projects and how to apply the criteria proposed for moral legitimacy.

The case study regards the construction of a railway tunnel near the foundations of the Basilica of the Sagrada Familia, a monumental church in Barcelona, Spain, part of which was declared a World Heritage Site by UNESCO. In the elaboration of this case study we have employed published material -mainly from news media, significant documents related with the construction of the tunnel, reports by experts and relevant organizations, personal interviews with people involved in or affected by the project, and with engineers and other experts in this type of construction.

We will structure this paper as follows. Firstly we analyze the concept of "moral legitimacy" and "social license to operate" and then discuss the relationship between the two concepts. Secondly, we develop reasonable criteria to evaluate moral legitimacy in the case of controversial projects. Thirdly we describe the case study, pointing out particular problems regarding SLO that it involves. Fourthly, we apply the criteria we 
propose to evaluate moral legitimacy to this case and discuss the decision taken in the case.

\section{Moral Legitimacy and Social License to Operate}

\section{Moral Legitimacy}

According to Foldvary, "Moral legitimacy means in accord with the rules of an ethic (...) [It] is relative to a moral standard.” (2012, p. 724). On their part, Baur and Palazzo stressed that moral legitimacy is connected to normative ethical theory, and added that this link prevents 'the attribute 'moral' from boiling down to an empty phrase and provides normative orientation when judging moral legitimacy.” (2011, p. 584). Similarly, we suggest that the moral legitimacy of a business or of a particular project or activity is based on sound ethical principles. Such legitimacy provides moral sense to executives and helps them to convince the firm's stakeholders and the general public of the ethical acceptability of their business or of particular activities or projects they are carrying out.

We take these "sound ethical principles" from the Aristotelian tradition (e.g., Chappell 2006), although other scholars may propose a moral legitimacy based on different ethical theories, e.g, Utilitarianism (see, e.g., Snoeyenbos and Humber 2002; Mukerji 2013, Demuijnck 2014), social contracts (Dondason and Dunfee 1999; see also Wilburn and Wilburn 2011) and discursive ethics (Palazzo and Scherer 2006; Baur and Palazzo 2011, see also a criticism in Willke and Willke 2008) based on Habermas (1990).

We accept that, "if moral legitimacy has a universal meaning, as implied by global justice, this implies that the moral rules by which to judge legitimacy are also universal, applying to all persons. A universal ethic would have to transcend culture and not be dependent on the beliefs, values, and biases of particular individuals" (Foldvary 2012, p. 724) (Emphasis added). Some may argue that it is difficult to find clear universal and unchanging moral principles, or a fixed objective reference, but at least moral principles are more stable than the social perceptions or partisan interests of certain stakeholder groups.

Aristotelian ethics is a moral system which transcends culture and avoids the biases of individual interests. Aristotle presented justice as having a substantive content which concerns both governmental and corporate activities within society, apart from 
interpersonal relationships. In Aristotle's words, "governments which have a regard for the common interest are constituted in accordance with strict principles of justice" (1984, III, 6), and justice is a virtue expressed in dealing fairly with other people (Aristotle 1912, Chap. 4).

Developing Aristotle, Aquinas added that "justice is a habit whereby a man renders to each one his due by a constant and perpetual will" (1981, II-II, q.58, a.1). This approach coordinates private and public activities through a set of context-invariant, justiceoriented norms (Dierksmeier and Celano 2012), which seems particularly appropriate to controversial projects of public interests, where both private and public spheres concur. Aquinas also provided the bases of the Triple Font of Morality Theory (Arjoon 2006, Melé 2012, pp. 57-66), which we will use to formulate our proposal below.

On the other hand, within the Aristotelian tradition, it is generally accepted that the state and intermediate associations between the individual and the state, including business firms (Fort 1996), find their moral legitimacy in their contribution to the common good (Maritain (1947). The common good for Aristotle, "is the good of the polis and of each citizen." (Sison and Fontrodona 2012, p. 214) That is, the good of the political community -and also smaller communities- somehow shared by those who are members of such a community. Sharing of common good entails participating in the good life. Aquinas argued that “a man's will is not right in willing a particular good, unless he refers it to the common good as an end" (1981, I-II, 19, 10). However, the submission to the common good is not universal at all. Aquinas adds that "a man is not ordered to the political community according to his entire being and all he has." (1981, I-II, 21, 4 ad 3) This could be interpreted as meaning that the common good is above particular interests, although the common good includes particular goods related to human flourishing. More specifically, the common good includes respect for human rights and promoting human relations based on ethical principles and common ethical values which can be found in the major religions and wisdom traditions (Melé, 2009a, p. 51).

Although discussion of the foundations of moral legitimacy would require much more space than this article permits, this short exploration allows us to suggest that the Aristotelian concept of substantive justice and the common good as key reference could be a good foundation to develop criteria for evaluating moral legitimacy. This is what we will try to do below. 


\section{Social License to Operate}

According to Wilburn and Wilburn (2011) the notion of SLO was developed as a response to a United Nations initiative in 2004, requiring industries that operate in the territories of indigenous people to secure free, prior, and informed consent. In this context SLO has often been presented as a pragmatic approach to avoiding risks derived from community anger, protest and boycotts, or for improving reputation. In addition, although many companies are adopting SLO, "because it protects their interests, many others are using it as a way to ensure that there is commitment to norms and values as they move into developing countries." (Wilburn and Wilburn 2011, p. 13)

In the last few years several related definitions or descriptions of SLO have emerged. A short review will give us an idea of the content generally associated with this concept. Salzmann et al. (2006) defined SLO as "the degree of match between stakeholders' individual expectations of corporate behavior and companies' actual behavior". Wilburn and Wilburn quote from The Ethical Funds Company: “A company can only gain a Social License to Operate through the broad acceptance of its activities by society or the local community. Without this approval, a business may not be able to carry on its activities without incurring serious delays and costs" (2011, p. 4). This is not overly different to Slack's view (2008) that corporations generally use this expression "to refer to some kind of approval they must obtain from local communities in areas where they operate (as compared to the legal license they must obtain from governments)". Similarly, a social license to operate has also been also related with interactions initiated by a company with the community where it operates in order to be a better community partner (Aylward, 2011).

Prno and Slocombe (2012, p. 248) went further by suggesting that the SLO can be seen as an institution (rights, rules and decision-making procedures), since SLO basically are "rules" (i.e., the expectations both parties have in regard to one another); The Minerals Council of Australia (2006) understands SLO "an unwritten contract between the industry and the communities in which it operates". However, beyond this contract there is also an objective reference: sustainable development: "This license goes beyond strict compliance with regulation, and requires companies to demonstrate a commitment to sustainable development throughout their operations" (Ibid). 
The call for papers of the 2013 meeting of $\mathrm{EBEN}^{2}$, to which this paper was firstly presented, considered two meanings of license to operate - one which was narrow and another which was wider. In the narrow sense "the 'license to operate' means the stakeholders' approval of a particular business project that can affect their lives". This view is not unlike that of The Minerals Council of Australia and others mentioned above. The wider meaning is "the acceptance or non-acceptance of the expansion of profit-seeking business into sectors of activity that, at least in Europe, were formerly performed by the state or non-profit institutions (healthcare, education, utilities, etc)". The call added that "broadly, the 'license to operate' could refer to an implicit social contract between corporations and society at large". The narrow definition - stakeholder approval -has probably been the most usual understanding of the concept, at least in extractive industries and controversial construction projects, such as public works.

There is also great agreement on the practical importance of social license to operate. RDS Partners, for instance, hold that "the social license to operate has become the buzz term as industries and companies come to terms with changing social expectations about industry development and accountability" (2012, p. 3). They went even further in stating "At the heart of economic development, planning and approval is social license to operate" (Ibid). Although this latter statement may seem a little exaggerated, there is no doubt about the increasing importance given to such license. From a different perspective Nelsen affirmed that the SLO creates "a forum for negotiation whereby the parties involved are heard, understood and respected" (2006, p. 161).

Benefits of obtaining SLO have often been pointed out, as have the negative consequences that occur when such license is not achieved (Slack, 2008; O'Keefe, 2009). In the mining sector, according to Ronald Smith -an industry expert who has experience in the activity in developing countries in Africa, especially Ghana- the benefits of a social license to operate are almost self-evident. "The local community is a source of labor and services, and people want to contribute, usually in excess of what mines can offer them. When a mine is in operation, local community members can frequently suffer from rising prices and costs while access to land for farming and other uses is reduced. Mines have significant impact on communities, hence the need for a social contract to operate" (personal communication of Ronald Smith, in Aylward 2011).

\footnotetext{
${ }^{2}$ http://www.eben-net.org/?q=content/eben-annual-conference-2013. Accessed on March 30, 2014.
} 
Regarding the negative consequences of not obtaining SLO, Olander and Landin (2008) described two civil works cases. In the first a lack of SLO increased the cost by delaying the construction of a tunnel in Sweden for 4 years while a prolonged environmental inquiry and procurement process, including final approval to start construction, were conducted. The budget for project costs increased by $7 \%$, mostly because of stricter environmental requirements resulting from a better understanding of the risks involved in the project. In a second case a similar thing happened. There was energetic opposition to the extension of a railway line, which would be an important component of a link between Copenhagen and Oslo. A relatively small group of people who would be affected by the line convinced others to join them in asking for an alternative. The evaluation of this alternative by the National Railroad Administration, who promoted the project, showed that it was worse than that already chosen from both economic and technical perspectives. The interest group appealed the municipality's decision to approve the proposed plan, and the ensuing legal process lasted some six years. The initial evaluations were actually of poor quality and the proposed alternative was finally approved. Indirect costs increased significantly.

On his part, Corvellec (2007), after reminding us that SLO is still an unelaborated concept theoretically, concedes a practical value to it, since it can provide common tenets of stakeholder theory, corporate social responsibility theory or business citizenship theory. According to him, "organizations cannot run their operations unless the communities in which they operate accept their presence" (2007, p. 138). Furthermore, he added the pedagogical significance of this concept: "License to operate, like medieval corporate charters, are reminders that corporations are social as well as economic institutions and thus subject to public accountability and control" (2007, p. 139).

To sum up, there is no doubt about the importance of SLO but the concept does also have some limitations, as we will discuss next together with its relationship with moral legitimacy.

\section{Relationship between Moral Legitimacy and Social License to Operate}

Some authors (e.g., Suddaby and Greenwood, 2005, Salzmann et al., 2006) have pointed out that SLO is related with the concept of (social) legitimacy, generally understanding this concept is in the context of New Institutionalism (Powell and DiMaggio, 1991). According to this theory, the main goal of organizations is to survive 
and this requires not only succeeding economically, but also achieving social acceptation or legitimacy. Thus, the legitimacy of an organization derives from how the constituencies (stakeholders) of this organization perceive it at any given moment (Corvellec 2007, p. 139). Both license to operate and social legitimacy are, therefore, matters of social acceptance, but whereas license to operate remains in the possession of the organization until it is revoked, social legitimacy can vary over time. In contrast, moral legitimacy depends on ethical principles.

Sometimes moral legitimacy is defined in a way which is not dissimilar to that used to establish social legitimacy. This is the case of some authors (Tolbert and Zucker 1996; Barron 1998; Greenwood et al. 2002; Rindova et al. 2006) who associate moral legitimacy with "the evaluation of the organization as beneficial to the evaluator's social group" (Bitektine 2011, p. 158). One might have some reservations about terming this legitimacy as "moral", since the evaluation depends on a certain social group, and is therefore relative to their shared values. If a society is tolerant of some forms of corruption, for instance, or is not overly sensitive about labor rights, or lacks concern for the environment, such "moral legitimacy" becomes morally flawed. Similar doubts arise in cases of misinformation or emotional reactions.

Many authors who deal with controversial projects or business activities only focus on SLO, maybe considering that moral legitimacy is implicit in SLO. However, the explicit reference to moral legitimacy based on ethical principles provides an objective and higher reference beyond the interests of the parties, which can be divergent. Such divergence is a difficult problem to overcome when only SLO is considered, inasmuch as SLO may only respond to particular interests or perceptions of the social groups affected by a project or business activity. Furthermore, such interest may not be unanimously granted - different stakeholders may have different opinions and approval may or may not be forthcoming for a certain project or business activity. Ronald Smith, the mining expert mentioned above, points out the variety of conflicting wishes and demands from different interest groups that may concur in a business operation: "Young men are keen to obtain employment. Women are worried about price increases. Local government authorities are worried about erosion of power. And farmers complain about access to land". In addition, there is often no single representative through which the mine can communicate (personal communication of Ronald Smith, in Aylward, 2011). 
Another problem in which moral legitimacy and SLO is also relevant is that known as the NIMBY ('not-in-my-backyard') syndrome. This refers to the reaction to new developments by those who recognize that a facility is needed but they are opposed to its execution in their own locality or neighborhood.

The NIMBY phenomenon has been observed in controversial projects or activities, including civil works, energy projects including nuclear-related facilities, marine farming, marble quarrying and hazardous waste disposal facilities, and of course, mining (Matheny and Williams 1985; Connor 1988; Lake 1993; Dorshimer 1996; Burningham 2000; Greenberg 2009; Allen 2011; Devine-Wright and Moore 2012; Pelekasi et al. 2012, among others). Emotions and reactions which arise may be based on founded or unfounded fears, or as a strategy to seek some kind of extra compensation.

As noted above, moral principles are more stable than the partisan interests of certain stakeholder groups that are unwilling to grant companies a social license to operate. Within the Aristotelian tradition, the common good is above particular interests, and therefore the moral legitimacy is over SLO. These two arguments justify the primacy of moral legitimacy over SLO.

In both problems mentioned, moral legitimacy is, therefore, quite relevant. On one hand, moral legitimacy provides moral support in seeking SLO or for a particular stakeholder demand, while other demands for which SLO is sought lack such legitimacy. On the other hand, it can provide reasoned arguments to counter the NIMBY syndrome.

From a managerial perspective, moral legitimacy which has substantive justice and the common good as a reference is an excellent tool for executives, who, as noted in the introduction, must convince the general public that they exercise power in a justified manner.

\section{Criteria for moral legitimacy}

As noted above, substantive justice and the common good as key reference can be a sound foundation for moral legitimacy. However, such concepts are quite generic and some specification is required to apply them to the evaluation of the moral legitimacy of controversial project. 
Following the Triple Font of Morality Theory (Arjoon 2006, Melé 2012, pp. 57-66; see also Redin et al. 2014), we accept that in a moral evaluation of any decision one should consider the morality of the intended end and the means elected for such an end, with reference to justice including the contribution to the common good, as well as to the concurrent relevant circumstances of the action or activity and the foreseeable consequences - in the case of there being negative consequences these should be sensibly inferior to the benefits obtained.

These four elements: 1) the intended end, 2) means elected, 3) the concurrent relevant circumstances and 4) foreseeable consequences and their proportionality to benefits, allow us to establish four criteria to evaluate the moral legitimacy of a project with a possible impact on the social and natural environments:

(1) Contribution of the project or activity to the common good in a better way than other alternatives (intended end). The common good (Melé 2009b, pp. 233-236) refers to goods which are shared by those who belong to the community and which are potentially beneficial for all members of the community. They include socio-cultural aspects, such as respect for human dignity and human rights, safety, order and peace with justice, etc., organizational conditions, including access to health, educational, communications means, fair laws, and so on, and economic conditions, which can favor economic and human growth for both current and future generations in such a way that everyone can enjoy reasonable wellbeing. The goals of business activities or projects can be related to some of these aspects. In a negative sense, these activities cannot be contrary to or erode the common good. All things considered, the prudent decisionmaker should choose the optimal alternative in the concurrent circumstances and foreseeable consequences (see criteria 3 and 4).

(2) Morality of the means and procedures employed (means elected). All of these elements should be ethically acceptable in terms of substantive justice, including their contribution to the common good, or at least in not eroding it. In a very elemental way this is related with the popular ethical dictum "doing no harm" and "promoting good". This applies to project organization, technology and equipment used, and requires diligent active inquiry to ascertain the real risks of producing harm. Likewise, it requires communication of the benefits and negative impacts to the people affected, again with diligence and truth. The importance of truthfulness and diligence is made clearer in considering the second case by Olander and Landin (2008) mentioned above, where 
there were failures in truthfulness and due diligence. The evaluation of the alternative initially approved by the National Railroad Administration was poor and it was finally shown to be worse than the alternative proposed by the community.

(3) Analysis and ethical evaluation of the situation including stakeholder concerns and needs (concurrent relevant circumstances). We have also to consider that the initial situation can change by negotiating with the stakeholders and even obtaining certain cooperation from them, or at least an attitude of tolerance toward the project. Wilburn and Wilburn (2011) divide stakeholders into two groups: the vested and the non-vested. Vested stakeholder groups have a voice and a vote in the awarding of a social license to operate, while non-vested stakeholder groups have only a voice. A proper moral evaluation requires understanding the situation and this includes having sufficient knowledge of the stakeholder concerns, needs and even foreseeable emotions, such as their fear of possible risks or the previously-mentioned "not-in-my-backyard" syndrome. These factors may or may not be morally significant. They should be evaluated from the perspective of justice and the common good.

(4) Ethical evaluation of reasonably foreseeable consequences associated with the project and how to minimize possible damage or risks, and balance foreseeable negative consequences and benefits.

These four criteria can be contrasted with several analytic factors suggested to obtain SLO. Olander and Landin (2008), by analyzing two projects, found that the outcome of the stakeholder management process depended mainly upon how well the project managers presented the benefits and negative consequences resulting from the construction project. In addition, technical means must be appropriate, and effects of negative impacts should be minimized and, if possible, the benefits for all stakeholders maximized. More specifically, they suggest proceeding by analyzing five key factors: (1) analysis of stakeholder concerns and needs; (2) communication of benefits and negative impacts; (3) evaluation of alternative solutions; (4) project organization; and (5) quality of media relations. In another study, SDR Partners (2012, p. 6), focusing on fish framing, but with a more generic perspective than Olander and Landin, recommended the following as key success factors for building high levels of SLO: (1) robust collaborative partnership between community and company, (2) dialogue, and (3) transparency and accountability. There are many common points, but while criteria 
for moral legitimacy are based on ethical principles, the factors for SLO are addressed to obtaining social acceptance.

With this conceptual framework in mind let us describe a case study, which will be useful to illustrate this type of situation with controversial projects and we will then evaluate the moral legitimacy in the case by applying these four criteria.

\section{Case Study: A tunnel near to the foundations of the Sagrada Familia}

The railway of the Spanish high-speed train - termed AVE (Alta Velocidad Española) between the two principal Spanish cities, Madrid and Barcelona (Sants Station), was completed in 2008, and there was the understanding that it would then be extended to the border to connect with the French network and its direct route to Paris. This would require crossing Barcelona, which was the root of the controversy.

In the first proposal to cross the city the route was to follow the coast, parallel to the Mediterranean Sea, but this was not to the pleasing of the Barcelona city council, which had a more ambitious scheme. In response to the petitioning of the municipality, the route was amended in 1998 to one which would pass through the center of Barcelona, following a route under the street called Mallorca. This new alternative meant the creation of a new station La Sagrera - bigger than Sants Station- which would vitalize rail traffic for both passengers and freight and provide a fast connection between the airport and the city. In addition, this alternative provided the possibility of another station on the Passeig de Gracia - one of the principal avenues in the center of the city.

This alternative was finally chosen and in June 2002 an agreement was signed by the three administrations with competence over the works - state, regional government and municipal government - and by the Spanish state railway company. The budget was later fixed at $€ 179.3$ million, and the completion date in early 2012. The state-owned corporation ADIF, owned by the Spanish Ministry of Public Works, was assigned responsibility for the execution of the railway works. The construction was charged to an ad hoc union of three big Spanish construction companies ${ }^{3}$.

The project basically included the route between these two stations - Sants and La Sagrera - located at opposite ends of the city, approximately 5.5 miles apart. This

\footnotetext{
${ }^{3}$ Namely, Sacyr-Vallehermoso, Cavosa Obras y Proyectos and Scrinser.
} 
would entail constructing a tunnel of $10.4 \mathrm{~m}$ in diameter, which would be excavated by a $105 \mathrm{~m}$ long tunneling machine. Some thought that this was a very risky project, on account of the low-quality terrain of Barcelona. Nevertheless, this was not an insurmountable problem. It was argued that excavation by a tunneling machine is the least aggressive manner of conducting these types of project, and several of the city's metro lines had been successfully constructed in this fashion. The main controversy arose on considering that the AVE railway would pass only a few yards from the foundations of the Basilica of the Sagrada Familia (Holy Family) (Figure 1), a large Roman Catholic Church which is now a basilica ${ }^{4}$, a landmark of Barcelona and recognized worldwide.

\section{INSERT FIGURE 1 ABOUT HERE}

Citizens of Barcelona were, and indeed are, very proud of Sagrada Familia, a masterpiece of the architect Antoni Gaudí (1852 -1926). It is a great work of architecture; a jewel of art in stone. Although the construction of this church began in 1882 it is not yet completed. Even so, the monumental work is visited by more than two million tourists each year. UNESCO has declared the oldest part of the church, which was constructed under the personal direction of Gaudí, as a World Heritage site. The church has three façades, one of which -that of The Glory-is still to be started, and it is here that the tunnel would pass beside on the route along Mallorca Street.

Two lines of Barcelona Metro were also near the Sagrada Familia foundations. In the project, the AVE tunnel passes below one of these lines. A pile wall between the tunnel and the church would be constructed to isolate the foundations from deformations that might be generated by the tunnel (Figure 2). The pile wall is connected to a concrete block, and this in turn to a volume of earth with injected concrete to better isolate the tunnel.

INSERT FIGURE 2 ABOUT HERE

\footnotetext{
${ }^{4}$ The Sagrada Familia was dedicated by Pope Benedict XVI in person in November 2011, and elevated to the status of basilica by him.
} 
Of course, state, regional and local governments who had approved the project were in favor of the project, as was ADIF, the company responsible for the execution of the railway works. In contrast, the Board of Trustees of the Sagrada Familia (representing the ownership of the church) and other cultural institutions steadfastly opposed the project due to the threat it entailed. The president of the Board, Mr. Joan Rigol, explained that he had credible technical reports confirming the risk to the church that the high-speed train route would occasion ${ }^{5}$. UNESCO also took a position of acknowledgement of the risks, recommending that the route be changed, and if this were not possible, that security measures be strengthened. The report affirmed: "The World Heritage Centre and the Advisory Bodies consider that while the computerized studies may show a potential to bore a tunnel at this location, it should be a precautionary principle to avoid any potential threats to the World Heritage property" 6 . Jordi Bonet, chief architect of the Sagrada Familia works, highlighted the report of the UNESCO experts advising that the AVE route should be modified, explaining publicly that he had been pushing for such a change for a considerable time. He added that the Minister of Public Works had ignored the recommendations of the management team of the church works. Additionally, he considered it irresponsible to have a tunnel "less than four meters from the foundations". He added: "I wonder what the Minister would say should some damage occur. I've never understood this stubbornness". Mr Bonet reiterated that the route of the AVE was not only a risk for the Sagrada Familia, but also for the Casa Milà (La Pedrera), another notable Gaudí work, "which has much weaker foundations".

According to the Sagrada Familia Board, the main threats were (1) movements of earth around the excavation which could affect the foundations of the Sagrada Familia, (2) alterations of groundwater levels which could have a negative effect on the foundations of the church, and (3) vibrations produced both by the works themselves and also by passing trains which could result in damage to the structure of the church.

The neighborhood around the Sagrada Familia and even along Mallorca Street was strongly opposed to the plan. Numerous banners appeared in windows and on balconies in the streets close to the route of the tunnel, and to further the protest an association

\footnotetext{
${ }^{5}$ Retrieved from http://www.europapress.es/cultura/noticia-ave-presidente-patronato-insiste-hay-riesgosagrada-familia-ofrece-colaboracion-unesco-20100730122122.html on April 9, 2013.

${ }^{6}$ Retrieved from http://whc.unesco.org/en/soc/714 on April 9, 2013.
} 
was formed to demand going back to the initial plan ("Platform for AVE via the Coast").

Afterward political parties entered into the controversy. A member of the Spanish Parliament from the Popular Party (conservative), then the official party of opposition, backed an existing alternative route which followed Valencia Street -parallel to Mallorca Street- and which in its day had received wide support and no contention against its suitability. This scheme would have been possible without significant financial repercussions, and without delaying the construction project. According to the deputy this alternative, which previously had a wide consensus of support, would only have delayed the construction works by six or seven months, and have an impact of $€ 10-€ 12 \mathrm{M}$ on the $€ 400 \mathrm{M}$ estimated total cost of the construction project ${ }^{7}$. In contrast, the Mayor of Barcelona (socialist), affirmed that he didn't understand the "obsession of the Right" with achieving the halting of the AVE works, and pointed out that the scheme which would see the tunnel pass below the Sagrada Familia was subject to more technical controls than any other construction project had ever been. José Blanco, the Public Works minister affirmed that there was no risk to the Sagrada Familia, as had been demonstrated by many reports. He also emphasized that UNESCO had determined that the precautionary measures in place met with established safety regulations, and that any change would have meant the stalling of the works for months with the attendant highly-significant and unaffordable waste of economic resources ${ }^{8}$.

The communication media reflected the various opinions, mentioning principally the technical reports that recommended caution, and written in a language that few understood. Many remembered the attention-grabbing accident in works on an urban tunnel (Carmel neighborhood) in Barcelona in January 25, 2005. It was indeed one of the most serious emergencies of its type to occur in Barcelona ${ }^{9}$. This contributed to a fear among the population in spite of the existence of technical reports vouching for the safety of the works in the AVE project. All of this touched public opinion in the city.

ADIF was very parsimonious regarding communications to the public, and its managers generally opted to be silent rather than explaining their reasons.

\footnotetext{
${ }^{7}$ Ibid.

${ }^{8}$ La Vanguardia, Barcelona, June 22, 2010.

${ }^{9}$ The tunnel collapse caused no casualties, but 1,276 people were evacuated from their homes immediately. After 48 hours, a garage located nearby disappeared into the crater. Retrieved from El País online: http://elpais.com/diario/2007/05/16/catalunya/1179277652 850215.html on January 31, 2014.
} 
The situation took on unprecedented social and political importance. The handling of technical information by non-experts together with the confidentiality of the information in the hands of the specialists provoked serious doubts and fear among the population. The experts did not share a common position. Some assessed that the works would be detrimental, or should not be carried out due to the risks involved ${ }^{10}$, while others vouched for the harmlessness of the works ${ }^{11}$, assured that the project was sound and that having adopted adequate security measures there would be no risk for the Sagrada Familia ${ }^{12}$.

However, some opinions were more detailed than others in terms of calculations and other arguments. One of these was that of engineer Palencia (2008), who carried out an assessment in which all information available was analyzed. On the basis of rigorous calculations, he affirmed that there was no risk at all. He argued that the building might move about $2 \mathrm{~mm}$, which was within the tolerable limits, and less also than that expected only from the completion of the church, regardless of whether or not the tunnel was built. The company ADIF had this and other reliable reports, which included not only measurements of movements in the church during construction of the tunnel and forecasts, but also forecasts of future movements due to construction and the presence of the underground tunnel (permanent deformation by digging, alterations in the level of groundwater, and expected vibrations caused by the passage of the train). Based on these reports, ADIF was sure that the operations were completely safe regarding the integrity of the structure of the church.

The question was whether ADIF managers had the necessary moral legitimacy to go ahead in spite of the lack of consensus among those affected by the project.

\footnotetext{
10 Among these experts were the Director of the Departament of Mining Engineering and Natural Resources at the Universitat Politècnica de Catalunya and other engineers, architects, geologists and independent experts.

11 Among those, the consultancy firm INTEMAC, the consultancy grouping INTECSA-INARSA, the University of Oviedo, the Official College of Geologists of Catalunya, the consultancy firms Itasca, Tifsa and D2S Internacional, and the university professors Carlos Oteo Mazo, José María Rodríguez Ortiz and Eduardo Alonso Pérez de Agreda (source: personal knowledge of one of the authors)

12 Antonio Gens, Professor of Geotechnical Engineering at the Universidad Politécnica de Catalunya, gave an address at the Círculo Ecuestre de Barcelona on January 292008 with the title "Will the AVE which is arriving threaten the Sagrada Familia?" He spoke of similar projects (tunnels or excavation work below historic constructions) in London, Amsterdam, Rome, Madrid, Vienna, San Sebastian, etc. With the adequate security measures, such as those that had been taken in the case of the Sagrada Familia, he was able to affirm that "The risk associated with the construction of the AVE tunnel via Mallorca Street is reduced to the extent that it does not condition the choice of route". Similarly, he also explained in the presentation how the pile wall between the drilling works and the façade reduced the settling anticipated below the foundations of the church. Personal communication of Antonio Gens to one of the authors.
} 


\section{Discussion}

The vested stakeholders, who as noted above are those with a voice and a vote in the granting of social license to operate (Wilburn and Wilburn 2011) - in this case governments and the company -, were fully in agreement. Among the non-vested stakeholders (voice but no vote), there was no problem for the common stakeholders of the firm (basically employees, suppliers) either. The real problem came from other groups of non-vested stakeholders: the neighborhood and the Sagrada Familia Board, as well as from many Barcelona citizens, and their "public opinion", in which the idea that the tunneling works posed a real risk was predominant. The neighborhood feared possible damage to the Sagrada Familia and even to their homes. Thus, the NIMBY ("not-in-my-backyard") syndrome appeared: "Do this but not my neighborhood". The main concern of Sagrada Familia Board was the safety of the church in the face of tunneling, future vibrations and so on. Their position derived from feeling responsibility to do their best to avoid any risk to the Sagrada Familia.

Clearly, the positions of the various stakeholders in the project were not at all unified (Figure 3).

\section{INSERT FIGURE 3 ABOUT HERE}

ADIF did not have SLO to carry out the project, or, at best, it had only partial SLO, but did it have moral legitimacy?

\section{The four criteria for moral legitimacy}

At this point we can apply the four moral criteria proposed above:

(1) Contribution of the project or activity to the common good in a better way than other alternatives. The project would contribute to the common good in terms of infrastructure connecting people by high speed train with other cities of Spain and Europe. The evaluations of alternative solutions were made and the outcome was that the Mallorca Street option was the best in both technical and economic terms. As noted in the description of the case, the alternative chosen has permitted the creation of a bigger station - La Sagrera - vitalizing rail traffic for both passengers and freight, and 
the possibility a new station for the AVE in the city center of Barcelona-Passeig de Gracia - in addition to providing a fast and efficient high-speed link between the airport and the city. The alternative solution of changing the route to a street parallel to Mallorca would not necessarily have been more expensive. The company ADIF, as far as can be told from the information available, followed this criterion.

(2) Morality of the procedures and other means employed. The use of the tunneling machine is the least aggressive manner of conducting these types of project and is safe enough. Thus, the execution of the tunnel by means of the tunneling machine was the most suitable manner of dealing with the threats mentioned above. These types of works have been successfully carried out in numerous cities, with no significant damage. Reliable calculations also indicated that the risk of damage to the edifice was negligible. The moral evaluation of these facts leads us to believe that there is no reason to doubt the EDIF managers' behavior in inquiring about these means shows truthfulness and diligence.

However the communication of benefits and negative impacts left much to be desired. The policy of the company in charge of the tunneling, as well as that of the governments involved, could have been far better. ADIF lacked a sense of accountability and no convincing technical reports were made public; there were only statements saying that this was the best solution and that there was no risk at all. This is true, but there was probably a lack of diligence in communicating relevant information to neighbors and the Sagrada Familia Board in greater detail and in a more active way. People affected have the right to know about the real risks or the absence of risks through access to the relevant studies. Limiting the information to affirmations that there are no risks is not enough. Furthermore, this seems also to have worked against the company as the lack of agreement with these stakeholders may have been the cause of ADIF having to affront various legal proceedings, although the courts did always find in favor of the company, and so their position regarding the safety of the project was repeatedly confirmed. It should not be forgotten that while a good communication process neither guarantees freedom from irrational fears nor the existence of the NIMBY syndrome, it can limit them significantly.

To some extent this criticism could be extended to the media relations of the company, which were also poor. However the media reaction was not too bad; faced with two 
opposing views and a debate associated with political ideology, they generally did not take one side or the other.

(3) Analysis and ethical evaluation of the situation including stakeholder concerns and needs. The company probably did analyze stakeholder concerns and needs and other circumstances. However, the extent to which the situation was carefully evaluated in terms of emotions and reactions is not clear from currently-available information, nor is it clear if the rights involved were considered from an ethical perspective. Judging by the communication policy adopted, the suspicion is that these evaluations were probably not made; or if they were, then no note was taken of them. In addition, it seems probable that there was scant exploration of the possibilities of negotiation with critics in order to seek at least an attitude of tolerance toward the project.

(4) Analysis and ethical evaluation of reasonably foreseeable consequences. The consequences deriving from the project in terms of damage or risks were evaluated and minimized.

To sum up, ADIF contributed to a project in line with the common good of the society and carried out a rigorous study and risk calculations trying to establish the truth about the risks for the Sagrada Familia and for the neighborhood, and employed all types of means to minimize undesirable impact on the church. This gave partial moral legitimacy to the ADIF in going ahead with the project, but they failed in communicating the detail of benefits and negligible risks. Our interpretation is that ADIF did not feel the need to pay too much attention to communications policy, due to its certainty about the lack of risks in the project, and thus a minor part of moral legitimacy was lost.

\section{What happened?}

Finally ADIF decided to go ahead with the project and included some complementary measures following the UNESCO recommendations on monitoring the works, which they scrupulously followed. Thus, they installed a large array of sensors at strategic points of the church to detect any deformation of its structure. Additionally, they took further measures which were not strictly necessary, such as the pile wall between the foundations of the church and the AVE tunnel. Thus, the level of security measures demanded in the project was even greater than the necessary in constructing a separating wall and extensively monitoring the Sagrada Familia to make sure that 
deformations would be within permissible limits. It could even be said that the expense produced by the desire for security was excessive, and brought about cost increases.

On March 26, 2010 drilling began in the subsoil under Mallorca Street, and the tunneling machine started its work from La Sagrera toward Sants on April 2, 2010. The opposition to the project instigated legal proceedings requesting a restraining order on the works in view of the risk to the Sagrada Familia. The lawsuit was rejected by the Spanish High Court, on the grounds that although this Heritage site could not be left unprotected, "the protection of other public interests implicit in the construction of necessary infrastructure cannot be forgotten".

Several other appeals presented by the Board of Trustees of the church seeking suspension of the works were dismissed. The High Court considered that the Board had not provided any new evidence to justify the reconsideration they sought. The court stressed that the UNESCO reports showed that "everything rests on taking measures of correction, safety and control over the works in relation to the Sagrada Familia and the Casa Milà but nothing has been proven against the public works in progress, the detention or paralysis of which would involve very significant economic harm"13.

In October 2010 the tunneling machine bored the section of tunnel that passed in front of the Sagrada Familia. It didn't produce the incidents that some had predicted when they foresaw problems with the works and the structure of the church. This was highlighted in the Journal of the Professional Association of Civil Engineers of Catalonia which, in the December 2010 edition expressed satisfaction "for the thus far successful progress of the tunneling between Sants and La Sagrera, especially in the section which passes the Sagrada Familia", adding that the association "had always had confidence in the viability of these works and throughout the process has asked for the due respect for the technical experts responsible for the execution of the Project. These are professionals of worldwide renown and have here acquired great experience in the boring of tunnels in urban environments" ${ }^{14}$.

On September 212011 the President of the Board of Trustees of the Sagrada Familia announced his resignation, without linking this to the tunnel. In declarations to radio media he recognized that effects of the AVE route remained to be shown, but he saw

\footnotetext{
13 Ibid.

${ }^{14}$ Revista del Colegio de Ingenieros de Caminos, Canales y Puertos de Catalunya, no. 18, December 2010.
} 
two far from insignificant risks: "the vibrations due to the tunnel passing so closely to the foundations" and that "subsoil water levels rise".

On January 8, 2013 the section of the AVE track between Barcelona and Figueres - a town close to the Spanish-French border - was officially inaugurated. It came into service the following day without any signs of the problems that had stirred such controversy.

Jäger and Katzenbach (2011) carried out a technical analysis of the tunnel project and the works on completion, and of their influence on the Sagrada Familia. Their report stated that ground deformation levels due to the activity of the tunneling machine were measured at 2.5 times less than the permissible limit ${ }^{15}$. Their report also considered the vibrations and oscillations of groundwater levels as potential sources of damage to the structure of the church, but these effects are rated as negligible. Similarly, the rate of deformation or cracking in the structure of the church was studied, and again, it was concluded that the effect of the tunneling works, even months after the boring process, was also negligible. Further, it stated that the level of preventative safety was extremely high and that levels of monitoring and follow-up were exhaustive.

According to Professors Gonzalo Ramos and Antonio Gens ${ }^{16}$ of the School of Civil Engineering of the Universitat Politècnica de Catalunya, who had acted as consultants to ADIF for these works, the level of risk control adopted was more than sufficient.

Consciousness of the risks disappeared over time, and the company is no longer criticized regarding this project.

On its part, the Journal of the Professional Association of Civil Engineers of Catalonia, after stressing the desirability of avoiding political controversy over the tunnel project, added a comment on behalf of the Association connected to moral legitimacy and SLO:

With this request, the Association is aware that citizens are to receive all necessary information and demand the highest security for involvement in their

\footnotetext{
15 Jäger and Katzenbach (2011) affirmed: "Concluding the interpretation of all measured deformations at Sagrada Familia and at the Mallorca Street, all systems show a similar value of app. 0.10 to $0.20 \mathrm{~cm}$ of settlements, which is at least 2.5 times less than the strictest predefined threshold value and is in the range of or slightly above the measurement accuracy".

${ }^{16}$ Interviewed by one of the authors in February 2013.
} 
daily activity is negligible or minimal. However, this right cannot be replaced by civic organizations interested opinions or policies that defend specific interests. ${ }^{17}$

\section{Conclusion}

Two normative approaches concur to give legitimacy to controversial projects something similar could be said regarding controversial business activities - moral legitimacy and social license to operate. We have argued that both are important, and controversial projects should seek to have both. Moral legitimacy provides moral support for SLO, which regards social acceptance. What is more, moral legitimacy, if it is well-founded, provides solid arguments for use in corporate communications and when negotiating with counterparties from whom the company is seeking to obtain SLO.

However, we have emphasized that there are times when SLO is not supported by moral legitimacy. Particular interests, fear without a rational reason, or what is termed the NIMBY (non-in-my-back-yard) syndrome, can lack moral legitimacy. In addition, different people or stakeholders can have different opinions, and these disagreements affect whether or not a project has SLO. The case study presented here, on the construction of a tunnel crossing Barcelona near the foundations of the Sagrada Familia monument, is an illustrative case of this problem.

Moral legitimacy is based on stable values and principles moral legitimacy, while the moral sensibilivity of a community is based on particular interests and can change over time. In addition, as noted, moral legitimacy provides an objective reference, while stakeholder perceptions can be influenced by fear or a lack of reliable information, or moved by illegitimate interests.

We have argued in favor of moral legitimacy based on substantive justice and the common good, in line with the Aristotelian tradition and the subsequent development of this by Thomas Aquinas. Our approach shows the right thing to do in terms of substantive justice, which takes the common good as the key reference. This goes beyond particular interests and even the interest of the majority, which may deny the

\footnotetext{
${ }^{17}$ Revista del Colegio de Ingenieros de Caminos, Canales y Puertos de Catalunya, no. 18, December 2010.
} 
rights of a minority. It also overcomes pragmatic attitudes which seek peer approval rather than doing good.

We have proposed four criteria to evaluate the moral legitimacy of a project or business activity and applied them to a case study. These regard the contribution to the common good in comparison with other alternatives; the moral consideration of the technical means and processes employed; the understanding of concerns and needs of the stakeholders; and the reasonably foreseeable consequences of the project and measures to minimize potential negative effects.

Last but not least, it is important to point out the importance of some virtues in managing controversial projects. We mentioned the necessity of practical wisdom in applying the four criteria and truthfulness and diligence to inquire about the real risks and possible damage. Of course, managers also need courage to face the situation and to implement the right decision.

Future research would entail developing these criteria in different contexts, and exploring them in other case studies, which could include business issues and engineering projects. 


\section{References}

Allen, G.: 2011, 'Public affairs and mining in Australia-a rescued license to operate', Journal of Public Affairs 11(4), 382-386.

Aquinas, T.: 1981[1273], The Summa Theologica (Burns Oates and Washbourne, London).

Aristotle: 1925, The Nicomachean Ethics (Oxford University Press, Oxford - New York).

Aristotle: 1984, Politics (Princeton University Press, Princeton).

Aristotle: 2012, Eudemian Ethics (Cambridge University Press, New York).

Arjoon, S.: 2006, 'Ethical Decision-Making: A Case for the Triple Font Theory', Journal of Business Ethics 71(4), 395-410.

Aylward, M.: 2011, 'What are the obstacles, challenges, and benefits of a social license to operate in the mining and metals industry?' http://blog.zintro.com/2011/04/11/whatare-the-obstacles-challenges-and-benefits-of-a-social-license-to-operate-in-the-miningand-metals-industry/. Accessed on October 3, 2014.

Barron, D. N.: 1998, 'Pathways to Legitimacy Among Consumer Loan Providers in New York City, 1914-1934', Organization Studies 19(2), 207-233.

Baur, D. and G. Palazzo: 2011, 'The Moral Legitimacy of NGOs as Partners of Corporations', Business Ethics Quarterly 21(4), 579-604.

Bitektine, A.: 2011, 'Toward A Theory of Social Judgments of Organizations: The Case of Legitimacy, Reputation, and Status', Academy of Management Review 36(1), 151179.

Brummer, J. J.: 1991, Corporate Responsibility and Legitimacy: An Interdisciplinary Analysis (Greenwood Press, New York).

Burningham, K.: 2000, 'Using the language of NIMBY: a topic for research not an activity for researchers', Local Environment 5(1), 55-67.

Chappell, T. (eds.): 2006, Values and Virtues: Aristotelianism in Contemporary Ethics (Oxford University Press, New York).

Connor, D. M.: 1988, 'Breaking through the NIMBY syndrome', Civil Engineering, 58(12), 69-71 58(12), 69-71. 
Corvellec, H.: 2007, 'Arguing for a license to operate: the case of the Swedish wind power industry', Corporate Communications: An International Journal 12(2), 129-144.

Devine-Wright, P. and S. Moore: 2012, 'Renewable Energy and the Public: From NIMBY to Participation', Review of Policy Research 29(3), 440-442.

Demuijnck, G., 'Utilitarianism' in Lüetge, C. (ed.), Handbook of the Philosophical Foundations of Business Ethics (Heidelberg, Germany: Springer, 2013): 297-312.

Dierksmeier, C. and A. Celano: 2012, 'Thomas Aquinas on Justice as a Global Virtue in Business', Business Ethics Quarterly 22(2), 247-273.

Dorshimer, K. R.: 1996, 'Siting major projects \& the NIMBY phenomenon: the Decker Energy project in Charlotte, Michigan', Economic Development Review 14(1), 60-2.

Foldvary, F. E.: 2012, 'Moral Legitimacy', in D. K. Chatterjee (eds.) Encyclopedia of Global Justice (Springer). Available at:

http://link.springer.com/referenceworkentry/10.1007/978-1-4020-9160-5 333.

Accessed on October 2014.

Fort, T. L.: 1996, 'Business as Mediating Institutions', Business Ethics Quarterly 6(2), 149-164.

Greenberg, M. R.: 2009, 'NIMBY, CLAMP, and the Location of New Nuclear-Related Facilities: U.S. National and 11 Site-Specific Surveys', Risk Analysis: An International Journal 29(9), 1242-1254.

Greenwood, R., C. R. Hinings and R. Suddaby: 2002, 'Theorizing Change: The Role of Professional Associations in the Transformation of Institutionalized Fields', Academy of Management Journal 45(1), 58-80.

Habermas, J.: 1990, Moral Consciousness and Communicative Action (The MIT Press, Boston).

Jäger, W. and R. Katzenbach: 2011, 'Monitoring during tunneling works for High Speed Railway AVE Tunnel, Section Sants-Sagrera in vicinity of UNESCO WORLD HERITAGE properties "Works of Gaudí” Sagrada Familia and Casa Milà • Barcelona • Spain, dated on August 6, 2011. Mimeo',

Koppell, J. G. S.: 2008, 'Global governance organizations: Legitimacy and authority in conflict', Journal of Public Administration Research Theory 18(2), 177-203. 
Kurze, S.: 2012, 'Precision tunneling in the vicinity of World Heritage Properties in Barcelona', Retrieved from www.vnconstructeurs.nl/Upload/Documenten/+sagrada\%20Familia\%20tunnel.pdf on April 24, 2013. .

Lake, R. W.: 1993, 'Rethinking NIMBY', Journal of the American Planning Association 59(1), 87-92.

Maritain, J.: 1947, The Person and the Common Good (Charles Scribner's Son, New York).

Matheny, A. R. and B. A. Williams: 1985, 'Knowledge vs. Nimby: Assessing Florida's Strategy for Siting Hazardous Waste Disposal Facilities', Policy Studies Journal 14(1), 70-80.

Melé, D.: 2009a, Business Ethics in Action. Seeking Human Excellence in Organizations (Palgrave-MacMillan, New York).

Melé, D.: 2009b, 'Integrating Personalism into Virtue-Based Business Ethics: The Personalist and the Common Good Principles', Journal of Business Ethics 88(1), 227244.

Melé, D.: 2010, 'Practical wisdom in managerial decision making', Journal of Management Development 29(7/8), 637-645.

Melé, D.: 2012, Management Ethics: Placing Ethics at the Core of Good Management (Palgrave MacMillan, New York).

Meyer, J. W. and W. R. Scott: 1983, 'Centralization and the legitimacy problems of local government', in J. W. Meyer and W. R. Scott (eds.) Organizational environments: Ritual and rationality (Sage, Beverly Hills, CA), 199-215.

Minerals Council of Australia: 2006, Enduring Value - the Australian Minerals Industry Framework for Sustainable Development. Retrieved from http://www.minerals.org.au/file_upload/files/resources/enduring_value/Self_Assesment revised.pdf on April 23, 2013.

Mukerji, N.: 2013, 'Utilitarianism', in C. Lüetge (eds.) Handbook of the Philosophical Foundations of Business Ethics (Springer, Heidelberg, Germany), 297-312. 
Nelsen, J. L.: 2006, 'Social Licence to Operate', International Journal of Mining, Reclamation and Environment 20,161-162.

O'Keefe, T.: 2009, Social license provides freedom to operate. WattPoultry, USA (Retrieved from http://www.wattpoultry.com/license.aspx,

Olander, S. and A. Landin: 2005, 'Evaluation of stakeholder influence in the implementation of construction projects', International Journal of Project Management 23(4), 321-328.

Olander, S. and A. Landin: 2008, 'A comparative study of factors affecting the external stakeholder management process', Construction Management \& Economics 26(6), 553561.

Palazzo, G. and A. G. Scherer: 2006, 'Corporate Legitimacy as Deliberation: A Communicative Framework', Journal of Business Ethics 16(66), 71-88.

Palencia Rodríguez, J.: 2008, 'Dictamen Pericial 0001531/2007 de la demanda de la asociación plataforma l'AVE pel litoral y otras, dated on February 15, 2008. Mimeo', Pelekasi, T., M. Menegaki and D. Damigos: 2012, 'Externalities, NIMBY syndrome and marble quarrying activity', Journal of Environmental Planning \& Management 55(9), 1192-1205.

Powell, W. W. and P. J. DiMaggio: 1991, The New Institutionalism in Organizational Analysis (University of Chicago Press, Chicago).

Prno, J. and D. S. Slocombe: 2012, 'Exploring the origins of 'social license to operate' in the mining sector: Perspectives from governance and sustainability theories', Resources Policy 37(3), 346-357.

RDS Partners: 2012, 'Social Return to Investment'. Retrieved from http://www.edo.org.au/edotas/pdf/2012conf fudge_sroi methodology.pdf on April 23, 2013.

Rindova, V. P., T. G. Pollock and M. L. A. Hayward: 2006, 'Celebrity Firms: The Social Construction of Market Popularity', Academy of Management Review 31(1), 5071.

Salzmann, O., A. Ionescu-Somers and U. Steger: 2006, 'Corporate License to Operate (LTO) - Review of the Literature and Research Options'. Retrieved from 
http://www.imd.org/research/publications/upload/csm_salzmann_ionescu_somers_stege r_wp_2006_23.pdf on April 23, 2013.

Sisón, A. J. G. and J. Fontrodona: 2012, 'The Common Good of the Firm in the Aristotelian-Thomistic Tradition', Business Ethics Quarterly 31(2), 211-246.

Slack, K.: 2008, 'Corporate Social License and Community Consent', Retrieved from http://www.policyinnovations.org/ideas/commentary/data/000094 on April 23, 2013.

Snoeyenbos, M. and J. Humber, 'Utilitarianism and Business Ethics' in Frederick, R. E. (ed.), A Companion to Business Ethics (Oxford, UK: Blackwell, 2002): 17-29.

Suchman, M. C.: 1995, 'Managing Legitimacy: Strategic and Institutional Approaches', Academy of Management Review 20(3), 571-610.

Suddaby, R. and R. Greenwood: 2005, 'Rhetorical strategies of legitimacy', Administrative Science Quarterly 50(35-67.

Tolbert, P. S. and L. G. Zucker: 1983, 'Institutional sources of change in the formal structure of organizations: The diffusion of civil service reform, 1880-1935', Administrative Science Quarterly 28(22-39.

Wilburn, K. M. and R. Wilburn: 2011, 'Achieving Social License to Operate Using Stakeholder Theory', Journal of International Business Ethics 4(2), 3-16.

Willke, H. and G. Willke: 2008, 'Corporate Moral Legitimacy and the Legitimacy of Morals: A Critique of Palazzo/Scherer's Communicative Framework', Journal of Business Ethics 81(27-38. 


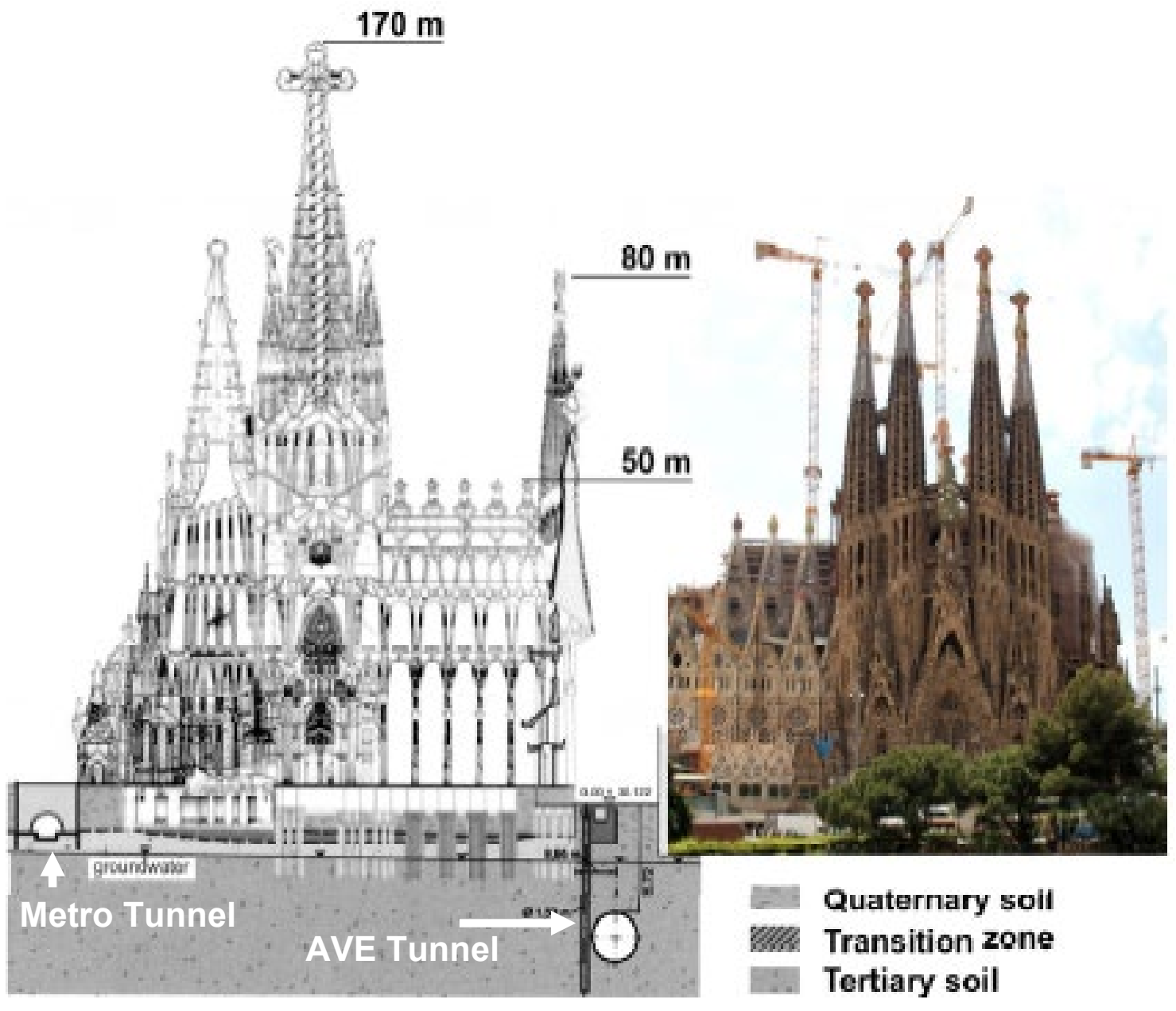

Figure 1. Section of the Sagrada Familia and the corresponding photograph. Source: Kurze (2012) 


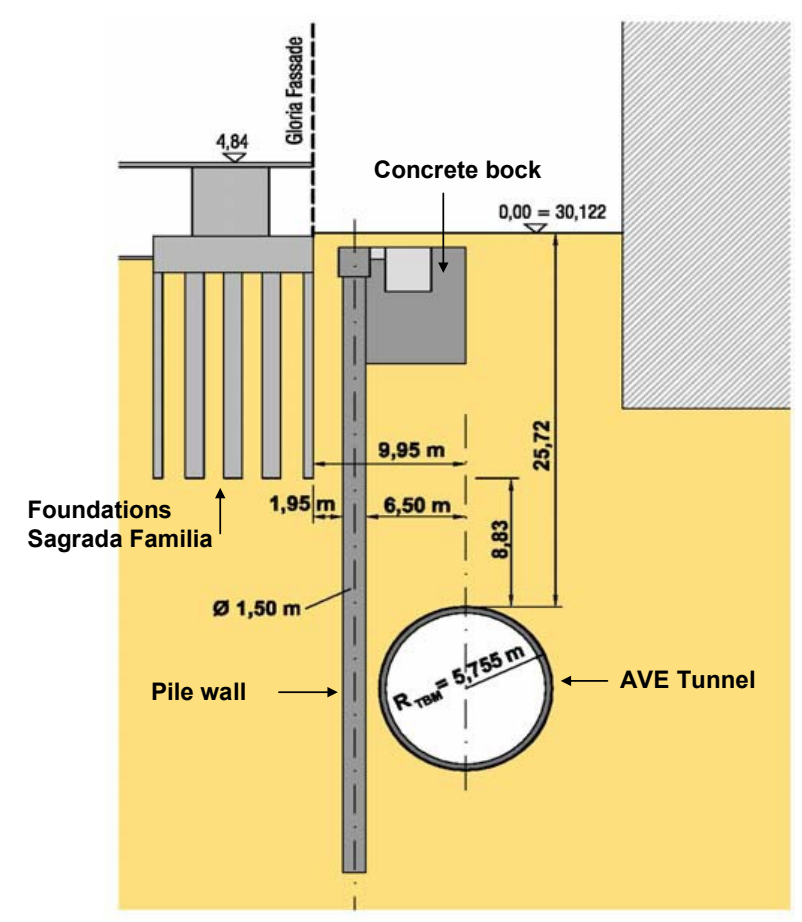

Figure 2. Detail of the situation of the tunnel.

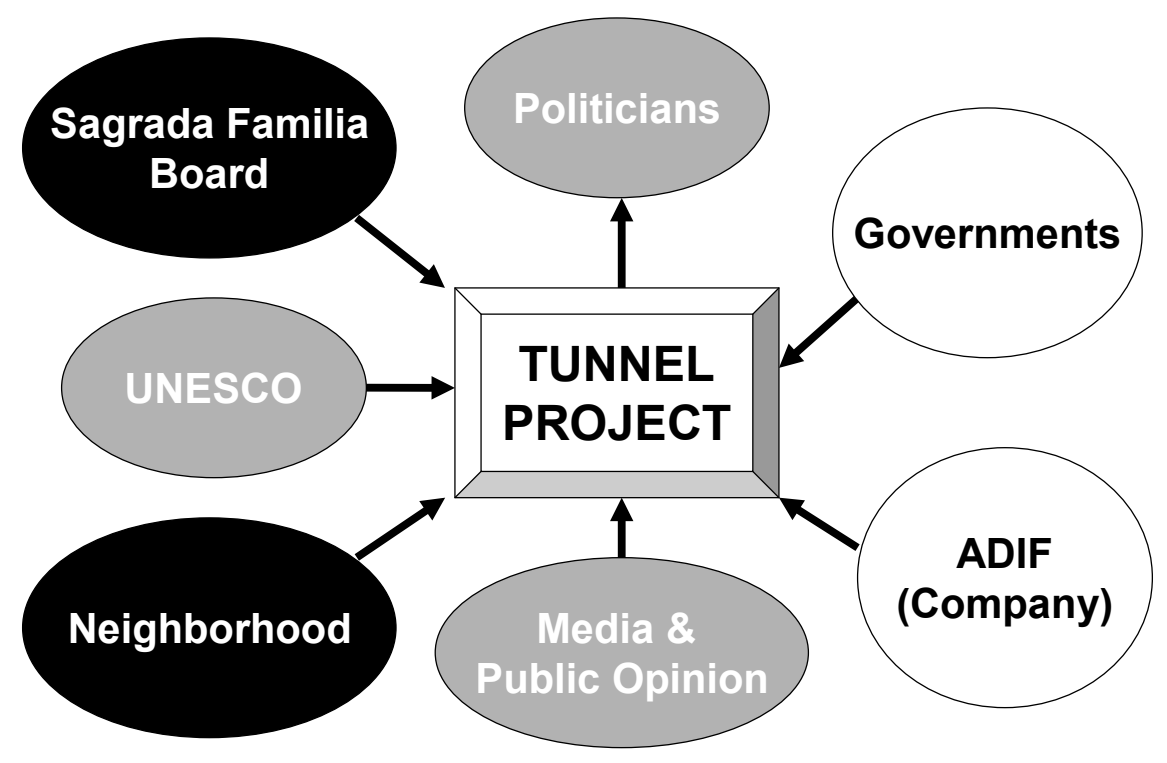

Figure 3. Stakeholders in the project; in favor (white), against (black), partially-against (gray) 
